Georgia State University

ScholarWorks @ Georgia State University

\title{
Propensity to Invest and the Additionality of Capital Transfers: A Country Panel Perspective
}

Jorge Martinez-Vazquez

Georgia State University, jorgemartinez@gsu.edu

Andrey Timofeev

Georgia State University, atimofeev@gsu.edu

Follow this and additional works at: https://scholarworks.gsu.edu/icepp

Part of the Economics Commons

\section{Recommended Citation}

Martinez-Vazquez, Jorge and Timofeev, Andrey, "Propensity to Invest and the Additionality of Capital Transfers: A Country Panel Perspective" (2012). ICEPP Working Papers. 66.

https://scholarworks.gsu.edu/icepp/66

This Working Paper is brought to you for free and open access by the International Center for Public Policy at ScholarWorks @ Georgia State University. It has been accepted for inclusion in ICEPP Working Papers by an authorized administrator of ScholarWorks @ Georgia State University. For more information, please contact scholarworks@gsu.edu. 
INTERNATIONAL CENTER FOR PUBLIC POLICY
International Center for Public Policy Working Paper 12-16

March 2012
Propensity to Invest and the Additionality of Capital Transfers: A Country Panel Perspective

Jorge Martinez-Vazquez Andrey Timofeev
GeorgaState University
ANDREWYOUNG SCHOOL

OF POLICYSTUDIES 



\section{International Center for Public Policy \\ Working Paper 12-16}

\section{Propensity to Invest and the Additionality of Capital Transfers: A Country Panel Perspective}

\section{Jorge Martinez-Vazquez Andrey Timofeev}

\section{March 2012}

International Center for Public Policy

Andrew Young School of Policy Studies

Georgia State University

Atlanta, Georgia 30303

United States of America

Phone: (404) 651-1144

Fax: (404) 651-4449

Email: hseraphin@gsu.edu

Internet: http://aysps.gsu.edu/isp/index.html

Copyright 2006, the Andrew Young School of Policy Studies, Georgia State University. No part of the material protected by this copyright notice may be reproduced or utilized in any form or by any means without prior written permission from the copyright owner. 


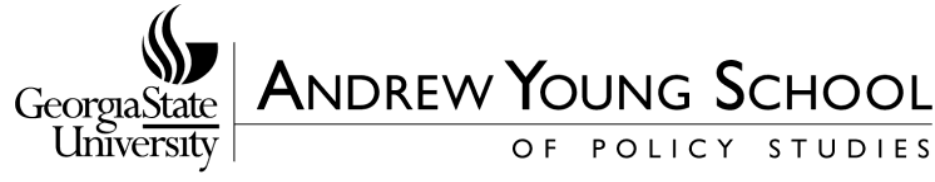

\section{International Center for Public Policy Andrew Young School of Policy Studies}

The Andrew Young School of Policy Studies was established at Georgia State University with the objective of promoting excellence in the design, implementation, and evaluation of public policy. In addition to two academic departments (economics and public administration), the Andrew Young School houses seven leading research centers and policy programs, including the International Center for Public Policy.

The mission of the International Center for Public Policy is to provide academic and professional training, applied research, and technical assistance in support of sound public policy and sustainable economic growth in developing and transitional economies.

The International Center for Public Policy at the Andrew Young School of Policy Studies is recognized worldwide for its efforts in support of economic and public policy reforms through technical assistance and training around the world. This reputation has been built serving a diverse client base, including the World Bank, the U.S. Agency for International Development (USAID), the United Nations Development Programme (UNDP), finance ministries, government organizations, legislative bodies and private sector institutions.

The success of the International Center for Public Policy reflects the breadth and depth of the in-house technical expertise that the International Center for Public Policy can draw upon. The Andrew Young School's faculty are leading experts in economics and public policy and have authored books, published in major academic and technical journals, and have extensive experience in designing and implementing technical assistance and training programs. Andrew Young School faculty have been active in policy reform in over 40 countries around the world. Our technical assistance strategy is not to merely provide technical prescriptions for policy reform, but to engage in a collaborative effort with the host government and donor agency to identify and analyze the issues at hand, arrive at policy solutions and implement reforms.

The International Center for Public Policy specializes in four broad policy areas:

- Fiscal policy, including tax reforms, public expenditure reviews, tax administration reform

- Fiscal decentralization, including fiscal decentralization reforms, design of intergovernmental transfer systems, urban government finance

- Budgeting and fiscal management, including local government budgeting, performancebased budgeting, capital budgeting, multi-year budgeting

- Economic analysis and revenue forecasting, including micro-simulation, time series forecasting,

For more information about our technical assistance activities and training programs, please visit our website at http://aysps.gsu.edu/isp/index.html or contact us by email at hseraphin@gsu.edu. 


\title{
Propensity to Invest and the Additionality of Capital Transfers: A Country Panel Perspective
}

\author{
Jorge Martinez-Vazquez and Andrey Timofeev* \\ International Center for Public Policy, Andrew Young School of Policy Studies, \\ Georgia State University
}

\begin{abstract}
This paper takes stock of the last 80 years of theoretical and policy literature on the issue of capital grants. In addition, we provide empirical evidence on changes in the relative importance of capital grants, and their impact on fiscal outcomes for a large number of countries. In particular, our empirical analysis explores two claims often used to justify capital grants in practice: 1) Due to political economy reasons, local governments tend to underinvest relative to the level desired by the national government. We test this claim by comparing the propensity to invest of subnational vis-à-vis national governments. 2) The administrative and efficiency costs of earmarking grants for capital use are justified by their effect of inducing additional investments by subnational governments. We test this claim by comparing the propensity to invest of local governments out of capital grants compared to their propensity to invest out of general purpose (non-earmarked) grants and own resources.
\end{abstract}

Keywords: capital grants, public capital, fiscal federalism

JEL Codes: H54, H72, H77

\footnotetext{
${ }^{*}$ Corresponding author: tel: (+1) 404-413-0230, fax: $(+1)$ 404-413-0244, e-mail: atimofeev@gsu.edu. We are thankful to Patrick Dever Jr. and Bauyrzhan Yedgenov for able research assistance.
} 


\section{Introduction}

Generally, for simplicity and transparency, intergovernmental transfers should not aim to achieve multiple goals with a single transfer instrument but rather have separate transfers for specific objectives. An important question is whether there should be separate transfers specifically to finance capital expenditures. If own-source revenues-including future revenues accessed through borrowing - are unable to provide local governments with adequate funding for the development of capital infrastructure, then the most obvious source of financing for local capital development is the central government budget. To the extent that the system of intergovernmental grants is to ensure vertical fiscal balance, the adequacy of available resources should be assessed in terms of the entire expenditure needs of subnational government functions, including capital infrastructure. While the system of grants should balance available resources with the entirety of capital and non-capital costs in the provision of subnational services, an important question is whether capital needs should be financed in an earmarked manner.

There appears to be consensus in the public administration literature that capital investments require more careful planning than non-capital projects because the consequences of errors of omission and commission in capital investments will be felt well beyond the current fiscal year through their impact on budgets, service provision, and economic development in the years to come. However, once the capital project requests have been prepared according to some rigorous planning procedures, should they be considered for funding separately from the requests on recurrent needs?

This question of capital transfers is relatively under-addressed in the theory and practice of intergovernmental fiscal relations. While there is a substantial literature that discusses the role of intergovernmental fiscal transfers in general, the amount of information available on specific 
practices with respect to intergovernmental capital transfers is sparse. In this paper, we attempt to take stock of the 80 years of theoretical and policy developments on this issue. In addition, we provide some empirical evidence on changes in the relative importance of capital grants, and their impact on fiscal outcomes, for a large number of countries. In particular, our empirical analysis explores two claims often used as justification for capital grants in practice: 1) Due to political economy reasons local government tend to underinvest relative to the level desired by the national government. We test this claim by comparing the propensity to invest of subnational vis-à-vis national governments. 2) The administrative and efficiency costs of earmarking grants for capital use are justified by inducing larger investments by subnational governments. We test this claim by comparing the propensity of local governments to invest out of capital grants compared their propensity to invest out of general purpose grants and own resources.

\section{Conceptual framework}

Conceptually, ring-fencing of a portion of public funds for investment purposes violates several principles of public finance management (see Gray et al, 1998, for best principles). First, it essentially creates dual budgeting by excluding a portion of public funds from policy-based prioritization. Second, allocation of funds by economic item (i.e., investment) shifts the focus of budgeting away from prioritizing policy goals to merely funding inputs. While government policies can guide the allocation of resources to sectors and priorities, investments alone cannot be assigned any priority independent of the programs and services that utilize these capital assets.

By artificially separating programs which aim at the same policy objective and preventing them from competing against each other within the total resource envelope, these 
arrangements can bias budgetary allocations toward more capital intensive approaches or vice versa. For example, traffic congestion during rush hours can be addressed through installing intelligent traffic light controls or posting police at major intersections. A policy-based prioritization would compare these two options along with other possible alternatives which achieve the same policy objective and select the most efficient solution. By contrast, ring-fenced capital budgeting would rank traffic lights installation relative to other capital projects (such as sewer extension) but not relative to non-capital solutions to traffic congestion. ${ }^{1}$ As a result, scarce public resources might not be channeled to problems of highest policy priority and problems that receive funding might not be treated with the most cost-efficient treatment.

Besides creating an artificial bias in favor of capital spending (or vice versa), separation of capital funding from financing of operating costs can lead to deferred maintenance. Budget unity allows for the finding of an optimal level of activities needed to maintain the fixed asset at its originally contemplated serviceability to avoid the capital costs of replacement for a longer period of time. However, under separation of capital funding, local managers might try to save on operating costs by not performing (deferring) maintenance at the proper time without perceiving the incurred capital costs of this strategy. ${ }^{2}$ Cromwell (1991) reports some empirical evidence that intergovernmental grants can create distortions to the optimal balance between constructing new infrastructure and maintaining the exiting stock. He finds 14 to 17 percent more resources allocated to the maintenance of private bus fleet in the United States compared to

\footnotetext{
${ }^{1}$ This problem can be mitigated if, in order to be considered for inclusion in the capital budget, projects have to pass a cost-effective analysis making sure that no non-capital projects can achieve similar objectives with the same or lower costs. Conceptually, given the high risks of errors of commission and omission inherent in capital projects, it is always more preferable to rely on a non-capital solutions unless the latter are much costlier. In practice, it might be the other way around as politicians will try to obscure the tax price of a project and shift the costs to the next administration by financing it from the capital budget.

${ }^{2}$ This goes beyond routine preventative maintenance and repairs but "also includes replacement of parts, periodic road resurfacing and other activities needed to maintain the fixed asset at its originally contemplated serviceability for its originally estimated life." (Spearman 2007, p. 72)
} 
the maintenance of the public fleet of similar vehicles. He explains this by the fact that the Urban Mass Transportation Administration (UMTA) pays 80 percent of regular transit vehicle replacement while no such federal subsidies are provided for maintenance. However, this finding is also consistent with the general argument that public managers have objectives other than cost minimization.

Systematically deferred maintenance can add up to considerable macroeconomic effects. When Rioja (2003) parameterized and solved numerically his macroeconomic model for a sample of Latin American countries, quantitative results showed that reallocating funds from new infrastructure to maintenance can have positive macroeconomic effects in those countries. A separate macroeconomic argument in favor of unified budgeting is that for an effective macroeconomic policy the national government needs to look at the effect of aggregate government spending including both current and capital expenditures (Axelrod 1988).

However, in countries where higher-level governments build local infrastructure rather than providing capital grants to local government, the distortions can be even worse. Thus, in Germany, the states (Länder) prescribe hospital capacity levels and finance investment expenditures but not operating costs or covering hospital losses. As a result, the state politicians have an incentive to overbuild hospital capacity and claim political credit for employment creation while settling local governments with the bill for operating costs, which over the years can be multifold of the construction costs (Wurzel 1999). Thus, the inefficiencies from capital grants are not just about the agency problem but also about the prevention of life-time costing of facilities. 
This conceptual argument against capital grants have to be balanced against a number of equally persuasive arguments for capital grants: 1) benefits of capital budgets; 2) internalization of spillovers, and 3) fiscal equity and fairness.

\section{Capital budgets}

The practice of separate channeling of intergovernmental resources to subnational capital expenditures might stem from the tradition of separate capital budgeting found in many countries. Capital budgets and associated capital grants first came into existence in Sweden and other Nordic countries in the $1930 \mathrm{~s}^{3}$ It was a strategy to promote economic recovery in the face of prevailing opposition to financing government outlays with public borrowing in the absence of national emergencies such as wars (Premchand 2007). In the following decades, the rationale and application of capital budgets shifted many times: reducing the appearance of current deficits in colonial India; vehicle of economic development under the central planning paradigm in the late 1950s; ensuring rigorous investment appraisal and financial planning in the 1960s; and more recently the introduction of accrual accounting in the 1990s. Thus throughout its eighty-year history, capital budgets have been used for at least three different purposes: 1) fiscal stimulus 2) economic development; 3) a "window to the net worth of public bodies" (Premchand 2007, p.89).

As result of this evolution of the role of capital budgets, today this practice takes different forms in different countries. In some countries, such as Australia, Chile and New Zealand, separate investment budgets are used as part of accrual budgeting with depreciation allowances charged to the current budget. Asian countries like Japan and South Korea use special budgetary accounts which are equivalent to investment budgets. Many developing countries have

\footnotetext{
${ }^{3}$ Reportedly in the United States first capital budgets were developed at the local level in the 1920s. Furthermore, in 1933 President Roosevelt in a federal budget separated ordinary expenditures, financed with tax receipts, from debtfinanced extraordinary expenditures necessitated by the Great Depression (Axelrod 1988).
} 
development budgets which accumulate foreign aid and loans but are often used for non-capital expenditures. Finally many countries have separate accounting for capital items - either in the framework of accrual accounting (e.g. federal budget in the United States) or under an economic classification system — but make no distinction in the budgeting.

Originally, capital budgets came into existence to circumvent balanced budget requirements by allowing loan financing of durable goods. But even when used for that reason, a strong theoretical justification for excluding capital investments from the balanced budget requirement exists only for investment into revenue-generating assets. The danger of breaking the budget unity by separating capital expenses is that there is no guarantee that in the future there will be a reduction in expenditure needs to offset the inherited obligations to service the loans used to finance the construction of assets. ${ }^{4}$ The seminal discussion of this issue by Musgrave (1939) highlights both the advantages and disadvantages of separate capital budgeting. Given these trade-offs, international experiences with capital budgeting have been diverse but are mostly related to compliance with borrowing constraints rather than ring-fencing of resources for capital investments. In the United States, there is no separation between capital and operating spending in the federal budget and budget process. ${ }^{5}$ However, more than half of US states receive executive capital-budget requests in a separate budget without unified budget totals, mostly to circumvent a statutory balance-budget requirement (Mikesell 1999, p. 227-28).

Rather than separation, the modern budgeting approach calls for a unified multi-year framework incorporating operating and maintenance costs so that the distinction between capital and non-capital projects disappears. Medium-term planning of commitments on the recurrent

\footnotetext{
${ }^{4}$ For example, in the United States some localities are still having special property rates to pay off the bonds issued to build schools for baby-boomers decades ago while the need for this classroom space dropped soon after the construction was completed.

${ }^{5}$ In the $1960 \mathrm{~s}$, a president's commission investigating budget concepts rejected capital budgets as it "could lead to greater outlays on bricks and mortar, and as a result, current outlays could suffer" (Premchand 2007, p. 91).
} 
side of the budget is particular important in transitional countries, where labor and civil service legislation does not allow for easy adjustment of human resources. Under this paradigm, rather than promoting a (dual) investment budget at the local level, the central government should provide a general policy-driven framework for unitary planning and budgeting, which might have special provisions for capital components of government programs. And once the central government, in order to avoid errors of omission and commission, instills proper planning procedures for capital components of local government programs, the central government should focus on the objectives and outputs of those programs when allocating intergovernmental transfers. For programs that deal exclusively with local affairs, the central government would be mostly concerned with overall vertical and horizontal fiscal balance, which is better addressed by general-purpose grants, possibly made conditional on adherence to national budgeting standards including capital planning procedures.

Overall, since capital budgets were first introduced in the 1930s the argument has not been settled about their appropriateness or even inescapability. While there might be some conceptual justifications for their use, the "main problem with the capital budget has been that it was never implemented in conformity with the conceptual framework, except in the first phase of its introduction" (Premchand, 2007, p. 108). In particular charging the depreciation allowances to the current budget, while being the core of the conceptual framework, had been dismissed in the public sector until the recent introduction of accrual budgeting in some countries. Furthermore, the practice of accrual and multi-year budgeting requires sophisticated capacity in terms of human resources and IT. In particular, accrual accounting requires sophisticated judgments about revenue projections and valuing assets that do not have any income stream, such as museums, military installations, and so on. These high capacity 
requirements explain the fact that as of 2003 only 5 out 28 OECD countries adopted full accrual accounting while additional 2 countries adopted modified accrual accounting without capitalization or depreciation of assets (Boothe 2007).

Rather than for their conceptual benefits, many of which can be arguably achieved without a separate capital budget, capital budgets are mostly used to instill more rigor of financial planning and overall discipline in less than perfect budgetary institutions we have in practice. In particular, in practice investment budgets mostly include infrequent irregular expenditure outlays that require special analysis as opposed to recurrent expenditure items for which some institutional memory and routines have been established. For that reason some longlived and expensive items that are routinely purchased by a local government (e.g. police cars) are commonly accounted for as capital items but included in the operational budget thus bypassing the planning rigor of the investment budget (Vogt 2007).

However, even in this more narrow practical view, different players see different virtues of capital budgets (Premchand, 2007). For accountants and financial planners, the main utility of capital budgets is probably facilitation of asset management. For economists, it is alignment of the costs of infrastructure among beneficiaries and over generations of taxpayers. For politicians, the main virtues are visibility of the expenditure outcomes and obscurity of the associated tax price. For the private sector, the main virtues are linking government borrowing to the specific projects and establishing the net worth of public bodies. These differences of perspectives translate into different definitions of capital expenditures, which for example would be required by economists to produce future benefits but for accounts it would suffice if they result in additional assets. This discrepancy of views can explain the continued division of opinions about capital budgets. 


\section{Capital grants and externality}

Conceptually, centralized capital grants can be normatively justified under two kinds of circumstances: 1) because of the existence/compensation for spillover of benefits from capital infrastructure across jurisdictions and 2) due to delegation of the construction of national infrastructure projects to the localities where this infrastructure would be located. In fact, these two justifications are related because a spillover of benefits occurs when a local government undertakes a capital project which actually should be undertaken by a higher-level government whose jurisdiction encompasses the entire area where the project benefits accrue. In practice, spillover of externalities is inevitable due to less than perfect correspondence between the varying benefit areas of the numerous types of public infrastructure and a limited number of scales of local government to assign them to. As Hulten and Schwab (1997, p. 141) put is: "...if each of these goods offers benefits to different subsets of the population, then logically we would need hundreds of overlapping levels of governments."

The externality justification for capital grants is exemplified by construction of interstate highways in the United States, which is federally planned and financed but implemented by state governments. These special cases call for earmarking of national financing not for general capital purposes but for specific capital projects that produce those externalities. Indeed, the central government would not want local officials to reprioritize these funds based on local needs, which by definition disregard spillover of benefits. Thus, there is normative justification for projectbased earmarking of capital grants in the case of externalities. ${ }^{6}$

\footnotetext{
${ }^{6}$ The only normative case for a formula-based funding earmarked for the general purpose of capital expenditures would stem from the central government role in economic stabilization. In this case, the central government would want these funds to be used for absorbing unemployed labor in public works while allowing local governments to identify projects according to local capital needs. For example, to recover from the economic recession of the early 1990s, the Canadian federal government was contributing one third of the total cost of local infrastructure projects broadly defined. The money was allocated among provinces on the basis of population and the rate of unemployment.
} 
In an example of externalities more relevant for less developed countries, for a large portion of capital infrastructure in rural areas the benefits are not entirely local but spill over village boundaries. Improving rural-urban linkages benefits both rural and urban populations by facilitating access to markets by both urban and rural consumers and producers. That is, lower transportation costs both bring cheaper foodstuffs for urban residents and reduce the costs of inputs for agricultural producers. The presence of these spillovers calls for intergovernmental financing in providing such infrastructure. However, under certain guidelines the administration of these infrastructure projects can be delegated to local authorities in order to achieve efficiency gains from utilizing their superior knowledge of local conditions.

However, when the spillover of benefits occurs, conceptually it requires intergovernmental financing of both construction and maintenance of such assets. This point was eloquently made by Hulten and Schwab (1997):

Spillovers are generated by the flow of services from the stock of public capital. We can increase that flow by either adding to the stock through investment or by improving the stock through maintenance. If the federal government is interested in providing the proper incentives to lower levels of government, it is hard to see why it should encourage state and local governments to invest in new capital but not encourage them to maintain that capital once it has been put in place.

Thus, conceptually spillover of benefits can justify earmarking of grants to infrastructure, which should include both the construction and maintenance costs. However, if the unit costs vary across localities, then the matching rates of Pigouvian subsidies should be inversely related to local costs and directly related to the extent of benefit spillovers (Martinez-Vazquez et al 
2011). In practice, the estimation of the extent of externalities is not a trivial matter. For example, no evidence of quantitatively important spillovers from state highways on private output is found at the regional level in the United States (Holtz-Eakin and Schwartz 1995). Furthermore, Boarnet (1998) finds evidence of negative spillovers in California as changes in county output are negatively associated with changes in street-and-highway capital in other counties while being positively associated with changes in street-and-highway capital within the same county.

By contrast, Pereira and Roca-Sagales (2003) find that the aggregate effects on private output from public capital installed in each Spanish region are due in almost equal parts to the direct and spillover effects. Cantos et al (2005) also find very substantial spillover effects on regional growth associated with the capital stock of transport infrastructures in Spanish regions. In addition, to different countries and different types of infrastructure, the different results could be due to capturing dynamic feedbacks in the VAR approach used by Pereira and Roca-Sagales (2003) unlike in the production function approach used by (Holtz-Eakin and Schwartz 1995) and Boarnet (1998).

Finally, given that external benefits of local infrastructure are spread over time, just like its direct benefits to local residents, the costs of its subsidizing should be spread across the generations of national taxpayers accordingly. However, it would be more practical to provide a one-time subsidy for the construction of these assets to avoid administrative costs of continuing subsidizing these external benefits as they occur in the future. Under accrual accounting, this upfront subsidy can be amortized in the national budget over years. In general, capital grants subsidizing construction of local assets can be used as a practical way of subsidizing future services produced with these assets on the basis of externalities or national policy objectives. 
(Varley, 2001). However, it will not completely eliminate the costs of future surveillance that would be necessary to make sure that these assets are used as intended; for example ensuring that social housing is allocated by local authorities according to the criteria envisioned by the national government. To make these national conditions enforceable, it could be more practical to provide national funding as a loan that will have to be paid back if local governments do not adhere to the conditions in the future.

\section{Capital grant and equity}

One of the open conceptual questions in the design of capital grant mechanisms is whether capital grants should address disparities in the accumulated stock of physical capital (sometimes referred to as "capital backlog" or "capital infrastructure gap"). If the existing local infrastructure is considered a true local good that has been built under optimal arrangements (so that those who currently enjoy the benefits also contribute to paying off the accumulated debt), there is no need to address this disparity with capital grants. Indeed, fiscally-induced migration will not arise here because the incentives to migrate into infrastructure-rich jurisdictions will be offset by the disincentives of higher taxation necessary to pay off the associated debt.

However, if the disparity in infrastructure resulted from some exogenous decision (e.g., discriminatory policy of the Apartheid regime in South Africa), this can cause fiscally-driven misallocation of population. In the case of income-generating assets, this would lead to disparity among localities in rent revenues, which has to be addressed with grants according to the fiscal equalization theory (Boadway 2004). In case of assets that do not generate income, under accrual accounting the income from these assets has to be imputed and accounted as expense in the recurrent budget and as revenue in the capital budget. Thus conceptually this disparity can be 
addressed by taking into account these imputed revenues and expenditure in the assessment of revenue capacity and expenditure needs as part of fiscal equalization.

When the infrastructure under consideration contributes to a redistributive government function (such as basic education or primary health care), then central government intervention might also be warranted. However, the exact form of this intervention is not necessarily clear. Some scholars suggest that, when regional disparities are exogenously given, the central government can also externally determine a fair or equitable distribution of physical infrastructure and introduce a series of earmarked grants to bring about the desired allocation of capital stock after a certain number of years (e.g., Levtchenkova and Petchey, 2004). However, this approach is not without problems. The main rationale for decentralization is allowing local players to make efficient decisions based on their superior knowledge of local conditions. The right mix of capital and non-capital inputs to the production of public services is one of the most important economic decisions. Therefore, externally imposing the level of capital infrastructure can lead to inefficient modes of service production

In general, acquisition of assets through separate budgeting procedures leads agencies to treat assets - once won in the struggle for a share of the government's capital budget - as a free good. This can lead to inefficient utilization of the assets due to the disregarding of the opportunity costs of the assets and also due to inefficiency in evaluating programs that utilize these facilities without accounting for the cost of capital. If one decides to address historical bias in the distribution of physical infrastructure, a better approach would be accounting for the impact of infrastructure availability on the recurrent costs of service provision when equalizing operational expenditure needs with unconditional grants. Thus, under accrual budgeting, as for example implemented in the New Zealand model of "new public management," a capital charge 
is levied on the net worth (as shown on its balance sheet) of each department to internalize the amortization of public assets in the production of public services (Laking 1999). Applying this approach to allocation of grants would impute potential capital income as part of the fiscal capacity of those "lucky" municipalities or alternatively assess the costs of leasing missing infrastructure as part of expenditure needs of those less fortunate. ${ }^{7}$

To the extent that the issue of unequal capital endowment concerns fiscal equalization, it is worth relating it to the 60 years of literature regarding efficiency-enhancing equalization grants (see Boadway 2004 for a comprehensive review). In particular, this literature provides some insights on how capital grants should treat differences in construction costs, differences in borrowing, and differences in infrastructure needs in terms of large number of students and so on.

Overall, the economic theory presents a very limited case for taking into account differences in the costs of producing subnational public services; that limited case is entirely based on inter-jurisdictional externalities. Concerning externalities from mobility of labor, equalization grants should take into account local costs only to the extent of publicness of local government services as private benefits of the local services are fully internalized in the individual's migration decision. However, most empirical estimates of the congestion parameter for local government services imply these are highly congestible (Albouy 2010). Given the empirically found privateness of local government services, there is little need for intergovernmental grants to take into account local costs from that perspective.

On the other hand, the theoretical justification for intergovernmental grants as a compensation for inter-jurisdictional spillover of benefits from local government services

\footnotetext{
${ }^{7}$ The potential capital income is quite real as exemplified by the fact that the fortunate half of Macedonia's municipalities that inherited high schools buildings finance two thirds of non-labor costs in secondary education through facility-generated income, such as renting out school gyms for fitness classes (Feruglio et al 2008).
} 
requires such Pigouvian subsidies to be inversely related to local costs of government services. The only possible case for efficiency-inducing equalization grants to be positively related to local capital needs is due to differences in the composition of population in terms of entitlement to various capital-intensive services. However, this conjecture articulated by Boadway (2004) has not been formally derived in the theoretical literature.

On the revenue side, efficiency-inducing equalization grants should take into account disparities in source-based taxes and local rents. Concerning disparities in residence-based taxes, only those disparities should be equalized that are determined by the differences in the composition of residents in those jurisdictions in terms of income-earning abilities but not their actual income as for example determined by local income-generating opportunities. These normative prescriptions for fiscal equalizations were derived using a single-period model. Conceptually these arguments could be extended to a multi-period setting so that a migration decision by a local resident is determined by the present value of future revenues and costs. However, this introduces one additional aspect of disparities namely the cost of inter-temporal smoothing or borrowing costs (Herrero-Alcalde et al. 2011). Thus, for two jurisdictions with identical streams of future revenues, the one with higher borrowing cost will have a lower present value of its revenues.

It is important to realize that within any country, with its own peculiar financing institutions, the ability to borrow is likely to differ markedly across sub-national governments. Local government borrowing from competitive capital markets - either through private financial institutions or directly from the bond markets- requires the local authority to be creditworthy by demonstrating its financial ability to repay its loan over time and technical capacity to manage its debt. As such, the very nature of capital markets assures that local government borrowing is 
likely to exacerbate horizontal imbalances: credit markets provide larger and wealthier regional and local governments with access to capital funding, while smaller and poorer local governments are typically excluded altogether from access to capital.

However, the issue of inadequate fiscal capacity of poorer jurisdictions is not specific for debt financing. Without being addressed with effective remedies, it affects the ability of local governments to finance their operating costs just the same way as their ability to repay debt. In fact, debt financing is only a tool for managing the flow of income and expenditures across time periods. If the flow of income is overall inadequate to finance the flow of expenditures rather than being mismatched across time, then debt financing cannot improve this situation. However, when a decentralized fiscal system is able to effectively address fiscal disparities by equalizing fiscal capacity and expenditure needs, including capital costs, this equalization will allow local governments to generate current surplus necessary to service their debt. Stable and predictable intergovernmental equalization and other grants contribute significantly to building the creditworthiness of local governments, if not just the same way as stable revenues from their own sources. An example is provided by the practice of intercepting sub-national government sources of revenues; the ability to intercept intergovernmental transfers can be seen by creditors as the most secure collateral. ${ }^{8}$

There is however one related issue that is specific to debt financing. Even when being able to generate revenue surpluses from their own sources and stable intergovernmental transfers, smaller jurisdictions might not be served by private markets because of the small size of their financial needs and relatively higher associated transactions costs. This suggests that policy makers need to consider alternative means of funding capital infrastructure in local

\footnotetext{
${ }^{8}$ At the same time the right to intercept intergovernmental transfers can discourage lenders' effort to monitor local government finances, and in some cases could be interpreted by these lenders as a promise of central government bailout. For example, Mexico has recently abandoned the practice of the intercept for these same reasons.
} 
authorities that lack access to capital markets. Capital grants are only one of several alternatives to private sector borrowing for financing local capital development in smaller jurisdictions, as we discuss immediately below.

Intermediary financial institutions specializing in local governments can help break the vicious circle in which smaller less-developed localities are restricted in funding infrastructure investments because of lack in capacity to manage borrowing. Although international practices vary substantially between countries, an intermediary institution can borrow in its own name and use the proceeds to purchase debt instruments of local governments; this type of intermediary is known as a bond bank. Alternatively, financial intermediaries that serve local governments might assemble and repackage municipal debt instruments and make them available to the market (e.g., create local bond pools). Such intermediaries can provide access to capital markets for smaller governments that otherwise would not get credit. Moreover, intermediation brings savings on the fixed costs of debt issuance thanks to standardized borrowing procedures and documentation, and technical assistance to local governments with capital planning, cash flow projections, and pre-structuring of loan packages (Freire and Petersen, 2004). While this intermediation is provided for a price, the fees associated with such intermediation for small-scale projects are generally less than the costs of bond issuance. In the United States, bond banks have been quite successful in leveraging "economies of scale on behalf of the small borrowers" since 1960s (Government Finance Group 1997, p. 29).

In practice, financial intermediation, especially when run by the national government, can have its own problems. Besides creating moral hazards, if the "soft" financial assistance from the center is institutionalized, it can also create a culture of long-term dependency and impede capital market development. Therefore, as a practical compromise, complementing borrowing 
with equalizing capital grants would allow the grants component to be means tested, thus representing an upfront payment of future gaps between debt service costs and revenue collections at some reasonable rates. Such upfront grants can be superior to subsidized interest rates and operating subsidies as they bring transparency and eliminate the need for future surveillance and administration (Varley 2001). The allocation of grants can be based on affordability analyses, targeting those projects that would become affordable only if subsidized with a partial grant.

Petchey and MacDonald (2007) argue that capital grants can be used as a "short-term option" in transition and developing countries until subnational governments get access to capital markets, tax handles or predictable intergovernmental revenue. Furthermore, they argue that under the aforementioned constrains, capital grants can be used as a short-cut for ensuring equal access to public services that have capital as the main input (e.g., transport). While this might be a valid point in some specific settings, it is not uncommon in developing countries to see local governments not having cash to provide access to education even at a "school under a tree" at the backdrop of aborted government construction sites and idle pieces of infrastructure, which were found to be of little use upon completion. For a broad range of public services allowing some degree of substitution between capital and non-capital inputs, the flexibility of, for example a sectoral block grant, would significantly enhance the chances of local governments to provide a larger access to these services than conditional grants earmarked to capital use or specific infrastructure projects.

In summary, normative theory gives some guidance for the use of capital grants and limits it to the cases of benefit spillovers, outsourcing of national projects, credit enhancement, and, in some circumstances, addressing historical disparities in the existing stock of 
infrastructure that are not the product of specific choices made by local governments themselves. These normative prescriptions are summarized in Table 1. For capital inputs to the provision of truly local public services, the theory suggests importance of unitary planning and budgeting possibly relying on inter-temporal financing through savings from past revenues and borrowing against future revenues.

\section{Capital grants in practice}

\section{Overall trends}

In practice, capital grants are used beyond the aforementioned theoretically justified causes (see Box 1). Out of 151 countries included in the 2010 edition of the IMF Government Finance Statistics, 96 countries report non-missing values for intergovernmental capital grants in at least one of the years from 1990-2008. One simple general reason for such a wide-spread use of capital grants is that real-world decentralized systems of government do not always follow the ideal model of decentralized public finance. As we pointed out earlier, lack of taxing powers affects the ability of local governments to finance their capital investments just the same as their ability to finance their operating costs.

Another powerful reason for the prevalence of capital grants is that central governments tend to treat capital development in a more centralized manner than recurrent programs. In cases where the provision of given services may have been devolved to local governments, it is not untypical to find central governments maintaining significant control over capital infrastructure decisions. This is despite the fact, that typically the share of subnational governments in capital expenditures of a country is twice their share of recurrent expenditures (Figure 1). This is true for countries in each income group and for the world average of the subnational share of capital 
expenditures, which is 60 percent compared to the 30 present of recurrent expenditures accounted for by subnational government.

\section{Box 1 International Practices and Best Practices in the Design of Capital Transfers}

International experience with the design of capital transfers shows that a large variety of approaches are used. Most countries use some form of capital transfers in support of subnational governments for specific sectoral expenditure areas such as roads, water and sewerage treatment plants, transportation, housing, education, health, and so on. Regarding the mechanism used to allocate capital transfers, country experiences vary from ad hoc allocation decisions to formalized approaches using pre-established formulae. Similarly, country experiences vary in flexibility from the least flexible "project-based grants" to unconstrained funds provided as part of a general revenue transfer. Often the amount of capital grants has to be matched with locally raised resources and the matching rate is sometimes inversely related to the local income (e.g. Finland)

The lack of information and the variety of approaches observed make it particularly difficult to generalize and extract lessons useful for just any country trying to establish or reform a system of capital transfers. At the risk of oversimplification, one can say that the typical country has a variety of capital transfers which are closed-funded in the national budget, have earmarked funds within specific capital expenditure categories, require some level of matching funds from subnational governments, and whose funds are allocated either by an objective formula or on a specific project basis. The variety of specific details in the design of capital transfers is a reflection of the many institutional features associated with capital transfers and the multitude of objectives that may be pursued by governments in this area. The range of objectives for capital transfers include: closing disparities in local infrastructure endowments, subsidizing capital projects with cross-jurisdictional spillovers of benefits, addressing vertical imbalance in the assignment of revenue sources, addressing lack of credit availability, and others.

Source: Martinez-Vazquez (2000). 
Even in such a highly decentralized country as the United States, for state and local infrastructure projects accepted for federal co-financing, the federal contribution has varied between 30 and 55 percent in contrast to its share of maintenance costs of public infrastructure, which never reached above 4.5 percent (Hulten and Schwab 1997). ${ }^{9}$ At the same time, throughout the 1956-1989 period, own revenues of state and local governments financed the bulk (68 percent) of public infrastructure construction in the United States while the federal grants accounted only for 18 percent with the remaining 14 percent accounted for by direct federal expenditures.

Similar to the case of foreign aid to developing countries, it is the higher visibility of infrastructure construction that biases intergovernmental grants towards capital earmarking so that for a legislative representative it would be easier to claim credit for new infrastructure built in his electoral district (Lee et al 2003). While most of the theoretical rationales for capital grants require project specific allocation as opposed to block grants, in practice such mechanism of grant allocation is also more susceptible to log-rolling than a formula-based allocation.

According to the IMF GFS data, on average, twenty percent of intergovernmental grants in the world is earmarked for capital use (Figure 2). This earmarked share is the lowest in OECD countries (13 percent) and the highest in upper-middle income countries (40 percent). From juxtaposing Figures 1 and 2, it is interesting to note that OECD countries are the most decentralized in terms of capital expenditures but at the same time use the least earmarking of intergovernmental grants for capital use. Similarly, a qualitative survey of governments revealed that three in five developed countries earmark transfers for capital use as opposed to four in five transitional countries, which can be explained by the legacy of central planning (OECD/World

\footnotetext{
${ }^{9}$ Here, the notion of 'core infrastructure' includes capital assets in such sectors as highways, mass transit, rail, aviation, water transport, water resources, water supply and sewage treatment.
} 
Bank 2003). In transition countries, capital transfers are often channeled through a plethora of extra-budgetary funds created within various line ministries (e.g., Romania until 2004).

Although potentially an inefficient budgetary practice, development budgets are still found in some (mostly developing) countries not only due to historical inertia but also because of external reasons. Donors prefer separation of the development budget from the regular budget because it is easier to monitor progress on investment projects than on general government programs. In addition, donors might prefer capital projects because of the misconception that capital expenditures are always more productive for development than current expenditures. By contrast, for grant allocation to its own members and prospective candidates, the EU requires each country to develop a single programming document, which shows how government priorities determine eligible projects, capital in nature or not, for example retraining of labor force.

In transitional countries, the practice of capital grants takes its genesis from the ad hoc delineation of responsibilities and resources during the first years of transition (on top of the long tradition of central planning). Because central governments were sensitive to political costs of wage arrears in schools and hospitals, they wanted local authorities to pay salaries first under the pretext that resources for capital expenses would be coming separately. Nevertheless, throughout the transitional countries, capital grants have played a smaller role in financing of local infrastructure than own revenue of local governments (often from the sale of assets) and borrowing, with the latter being more prevalent in Central Europe (Swianiewicz 2004). Throughout the world, capital grants account for about one third of net subnational investments and this share ranges from less than one-fifth in lower-middle counties to over a half in OECD countries (Figure 3). 
All in all, across the world, subnational governments account for almost two thirds of public investments, only one third of which is financed with capital grants, which in turn accounts for one-fifth of intergovernmental transfers. It should be noted however that, while the lowest share of grants (15 percent) is earmarked for capital use in the OECD countries, it accounts for the largest share of subnational investments (one-half) as capital expenditures play a much smaller role in the budgets of developed countries compared to the world average.

\section{Empirical hypotheses and estimation strategy}

Our empirical analysis explores two claims often used as justification for capital grants in practice. First, it is often claimed that, due to political economy reasons, local governments tend to underinvest relative to the level desired by the national government. Thus, Ahmad and Searle (2006, p. 389) argue that separating recurrent transfers from capital transfers could be appropriate in many low- and middle-income countries where "scarcity of financial resources and popular pressure to use them for immediate current spending may leave little for capital formation." Similarly, according to Boothe (2007, p. 192): "one of the key reasons for advocating a move to accrual accounting has been the view that during periods of deficit reduction, governments using cash accounting simply replace fiscal deficits with infrastructure deficits by ignoring the depreciation of public capital." Moak and Hillhouse (1975) suggest that, when under fiscal strain, local governments tend to postpone capital projects rather than expenditures for operating agencies. Similar evidence from surveys of coping strategies of U.S. cities was reported by Pagano (1993). We test this claim by comparing the propensity to invest of subnational vis-à-vis national governments.

Second, the administrative and efficiency costs of earmarking grants for capital use are often justified by the expected effect of inducing subnational governments to make additional 
investments into public infrastructure. We test this claim by comparing the propensity of local governments to invest out of capital grants compared to their propensity to invest out of general purpose grants and own resources.

The propensity of central and subnational governments to invest is modeled with crosssectional and panel-data regressions, while controlling for other determinants of public investments. In the appendix, we provide the complete list of explanatory variables that we considered in our regressions along with their definitions and sources of data.

We use two alternative empirical strategies: the between estimation explores propensity to invest in a cross-country analysis while the within estimation analyzes changes over time. Conceptually we cannot favor one specification over the other. The within estimation discards information on cross-country variation by country-demeaning (differencing from the country average over time) all variables. On the other hand without demeaning, we cannot control for some unobservable factors specific to each country. If these factors are correlated with some of the included regressors, then we are likely to obtain biased estimates using the between estimator.

Another econometric issue is a possible bias from endogeneity of capital earmarking. Indeed, in countries where subnational governments have lower propensity to invest, the national governments might do more earmarking of grants. The best response to this problem is a set of valid instruments - that is, variables that affect subnational investments only through their effect on capital earmarking of grants. Unfortunately, it is hard to identify variables that would be good instruments for the capital earmarking of grants. It is our hope that this potential endogeneity is partially mitigated in our panel data by including fixed country effects. 


\section{Estimation Results}

First, we report the estimates of the propensity to invest by subnational governments. In the first column of Table 2 we report the results of the "between estimation," based on the time averages of the longitudinal observations for different countries in our sample. All fiscal variables are normalized by total government revenues in a particular country. The included variables jointly explain about three fourth of cross-country variation in subnational investments. The subnational propensity to invest out of capital grants is estimated to be 0.69 with the 95 percent confidence interval between 0.24 and 1.13 . At the same time the subnational propensity to invest out of own revenue is estimated to be 0.13 with the 95 -percent confidence interval between 0.06 and 0.19 .

We can reject at the $1 \%$ significance level the hypothesis that the subnational propensity to invest out of capital grants is not higher than the propensity to invest out of own revenues (or recurrent grants for that matter). At the same time, the propensity to invest out of own revenues is statistically indistinguishable from the propensity to invest out of recurrent grants even at the $10 \%$ significance level. However, we can reject full additionality (that is the propensity to invest our of capital grants of no less than 1) only at the $8 \%$ significance level.

In the last two columns of Table 2 we report the results of the panel data analysis. In the second column we report the results of the fixed effects estimation based on the deviation from time averages for different countries in our sample. The included variables jointly explain about a quarter of the within variation in subnational investments. This approach should yield consistent but potentially less efficient estimates than the random effects model reported in the last column of the table. As the Hausman test does not find any systematic differences between 
the two panel data models, we will focus on the random effects model, which is expected to provide more accurate statistical inferences in the absence of consistency problems.

According to the random effects model, the subnational propensity to invest out of capital grants is estimated to be 0.62 with the 95 -percent confidence interval between 0.42 and 0.81 . At the same time the subnational propensity to invest out of own revenue is estimated to be 0.08 with the 95-percent confidence interval between 0.05 and 0.11 .

We can reject at the $1 \%$ significance level the hypothesis that the subnational propensity to invest out of capital grants is not higher than the propensity to invest out of own revenues (or recurrent grants for that matter). At the same time, the propensity to invest out of own revenues is statistically indistinguishable from the propensity to invest out of recurrent grants even at the $10 \%$ significance level. However, we can reject full additionality (that is the propensity to invest our of capital grants of no less than 1) at the $1 \%$ significance level.

Finally, we report the estimates of the propensity to invest by the central government. The purpose is to determine whether subnational governments tend to underinvest compared to the level desired by the national government. The propensity of the national government to invest can be defined in two alternative ways: relative to the own revenue of the national government and relative to the national expenditures other than grants. The estimates of the two alternative definitions of the propensity to invest are reported in tables 3 and 4 respectively. It appears that the propensity of local governments to invest out of own resources is considerably lower than propensity of the national government to invest, defined in two different ways. 


\section{Conclusions}

While in many developing and transitional countries some part of resources for local capital development has to come from the central government, conceptually it does not have to be through a transfer scheme separate from that for financing operational expenses. In theory, when the system of intergovernmental grants addresses fiscal disparities by achieving vertical and horizontal fiscal balance, this balance should allow local governments to generate current surplus necessary to service the debt required to finance capital investments. Furthermore, stable and predictable intergovernmental grants contribute to building the creditworthiness of local governments similarly to stable revenue streams from their own sources.

The existence of capital budgets and capital grants in practice is mostly justified by the departure of the real-life settings from the ideal model of fiscal decentralization due to political economy and institutional issues. Therefore, capital grants should not be analyzed with the ideal model but instead using a model featuring all those real-life issues. In this paper we attempt to undertake such positive analysis.

The IMF's GFS data show that typically the share of subnational governments in capital expenditures of a country is twice their share of recurrent expenditures. We find that most of public infrastructure in a typical country (possibly with the exception of low-income countries for which data are scarce) is built by subnational governments using their own or generalpurpose grant revenues. However, the small fraction of public infrastructure projects that are (co) financed by the national governments are subject to various strings attached.

We use the IMF' GFS data to examine the effect of capital grants on subnational government investments. Various estimators produce qualitatively similar results. As a midrange estimate we can quote the results from the random effects estimator, which is known to be 
arithmetically equivalent to a weighted average of the between- and fixed-effect estimators. According to the random effects model, the subnational propensity to invest out of capital grants is estimated to be 0.62 with the 95 -percent confidence interval between 0.42 and 0.81 . Thus, each additional dollar of capital grants is associated with between 42 and 81 additional cents of subnational investments. At any conventional level of statistical significance, we can reject full additionality, that is the propensity to invest our of capital grants of no less than 1 . Given this leakage, the administrative and efficiency costs of earmarking grants for capital use have to be balanced against their limited effect on investments by subnational governments.

If financing of capital costs is done separately for some, possibly external reason, then it should follow the same principles of intergovernmental fiscal transfers to prevent further efficiency losses. In particular, a formula-based capital development grant system could provide financial resources to local governments (those with greater infrastructure needs and less own resources) in order to assure a more equitable (pro-poor) development of capital infrastructure. Because of the transparency and predictability of a formula-based capital development grant system, local governments would be able to engage more easily in strategic planning of their development activities.

In many transitional countries, road funds represent a legitimate example of such transparent and predictable allocation. Fuel excises are collected nationally for administrative expediency but redistributed - ideally based on a formula, as for example in Latvia - among localities and earmarked for local roads (both construction and maintenance). In this case, intergovernmental redistribution is normatively justified by inter-jurisdictional externalities while excise-financing brings elements of benefit taxation by creating a link to road use. Under another example of formula-based capital grants, in the United Kingdom, the national target of 
delivering adequate-quality social housing is achieved through earmarked grants to local authorities based on a formula capturing the condition and rehabilitation costs of existing housing stock and demand for additional housing capacity (Petchey, Jeffrey and Garry MacDonald 2007) 
Table 1. Optimal design of intergovernmental financing of local capital needs

\begin{tabular}{|c|c|c|c|c|}
\hline $\begin{array}{l}\text { Objective } \\
\begin{array}{l}\text { Grant design } \\
\text { choice }\end{array}\end{array}$ & Revenue sharing/Adequacy & Fiscal equity & $\begin{array}{l}\text { Spillovers or } \\
\text { "externalities" }\end{array}$ & "Merit goods" \\
\hline $\begin{array}{l}\text { General } \\
\text { purpose vs. } \\
\text { capital grants }\end{array}$ & $\begin{array}{l}\text { Capital needs taken into account in } \\
\text { the allocation of general purpose } \\
\text { grants; capital earmarking under the } \\
\text { centralization of borrowing capacity }\end{array}$ & $\begin{array}{l}\text { Capital needs taken into } \\
\text { account in the allocation of } \\
\text { general purpose grants }\end{array}$ & $\begin{array}{l}\text { Earmarked for } \\
\text { the externality- } \\
\text { generating } \\
\text { activities }\end{array}$ & $\begin{array}{l}\text { Earmarked for the } \\
\text { merit goods }\end{array}$ \\
\hline $\begin{array}{l}\text { Global vs. } \\
\text { sector- } \\
\text { earmarked }\end{array}$ & Global & $\begin{array}{l}\text { A trade-off between formula } \\
\text { simplicity (perception of } \\
\text { fairness) and accuracy of } \\
\text { capturing disparities in capital } \\
\text { needs }\end{array}$ & $\begin{array}{l}\text { Sector- } \\
\text { earmarked }\end{array}$ & Sector-earmarked \\
\hline $\begin{array}{l}\text { Need } \\
\text { adjustment }\end{array}$ & $\begin{array}{l}\text { Only with respect to economic } \\
\text { infrastructure; Alternatively can be } \\
\text { addressed through separate } \\
\text { conditional/matching grants since } \\
\text { local economic infrastructure } \\
\text { produce vertical externalities by } \\
\text { increasing the yield of } \\
\text { national/shared taxes in the locality }\end{array}$ & $\begin{array}{l}\text { Differences in the proportion of } \\
\text { population groups entitled to } \\
\text { capital-intensive local services; } \\
\text { in case of inequitable } \\
\text { distribution of existing } \\
\text { infrastructure, imputed capital } \\
\text { income is subtracted from } \\
\text { expenditure needs }\end{array}$ & None & $\begin{array}{l}\text { Differences in the } \\
\text { proportion of } \\
\text { population groups } \\
\text { entitled to merit } \\
\text { goods }\end{array}$ \\
\hline $\begin{array}{l}\text { Cost } \\
\text { adjustment }\end{array}$ & $\begin{array}{l}\text { Only proportional to the extent of } \\
\text { vertical fiscal externalities. As with } \\
\text { other conditional grants, the optimal } \\
\text { matching rate can be inversely } \\
\text { related to the local cost level. }\end{array}$ & $\begin{array}{l}\text { For economic efficiency, cost } \\
\text { adjustment only if local } \\
\text { services are not fully } \\
\text { congestible (fully private); For } \\
\text { social equity, full equalization } \\
\text { of costs }\end{array}$ & $\begin{array}{l}\text { Inverse relation } \\
\text { to the costs }\end{array}$ & $\begin{array}{l}\text { Full equalization; } \\
\text { bottom-up costing in } \\
\text { the case of an assured } \\
\text { universal minimum }\end{array}$ \\
\hline
\end{tabular}


Table 2. Determinants of subnational investments

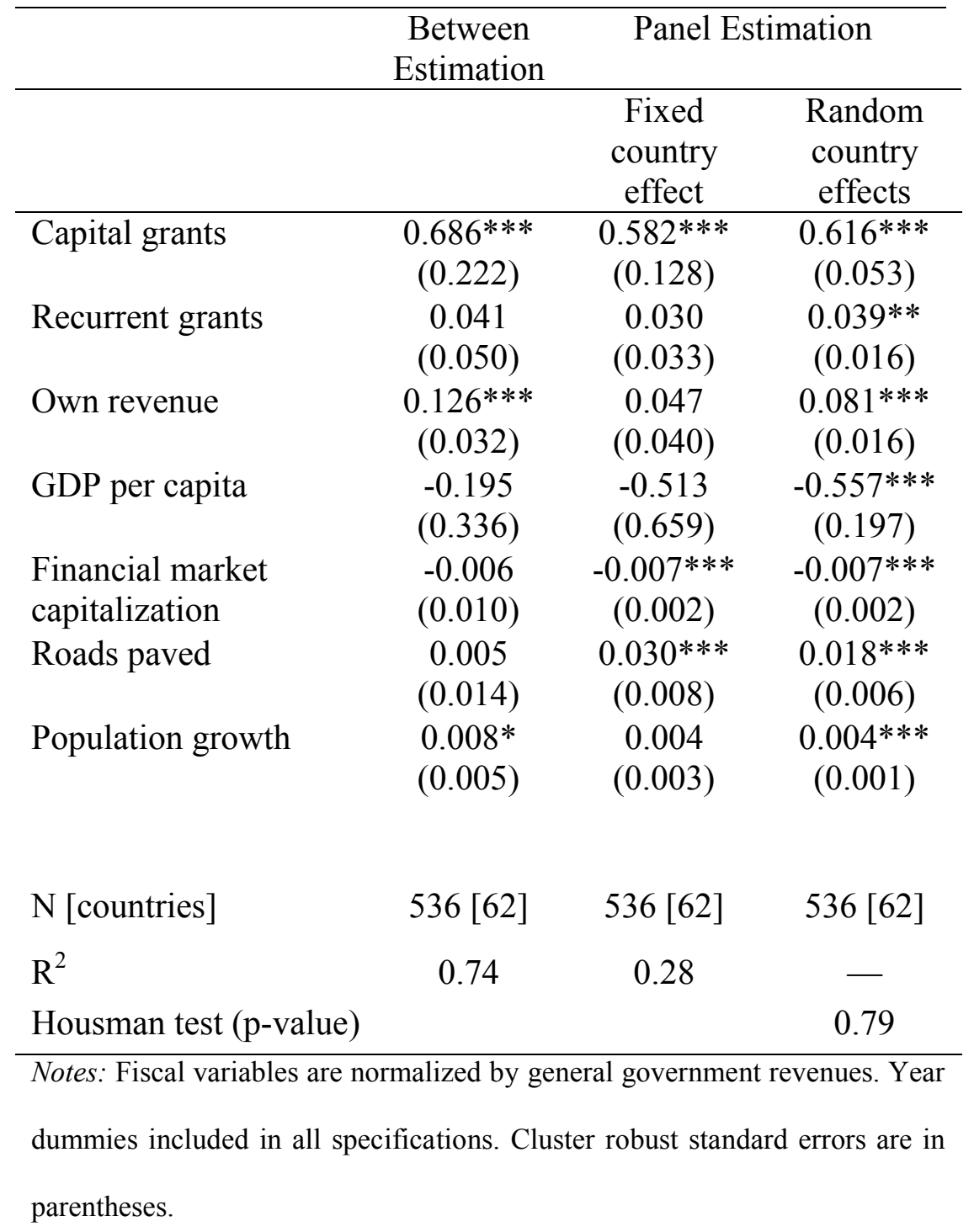


Table 3. Determinants of central government investments

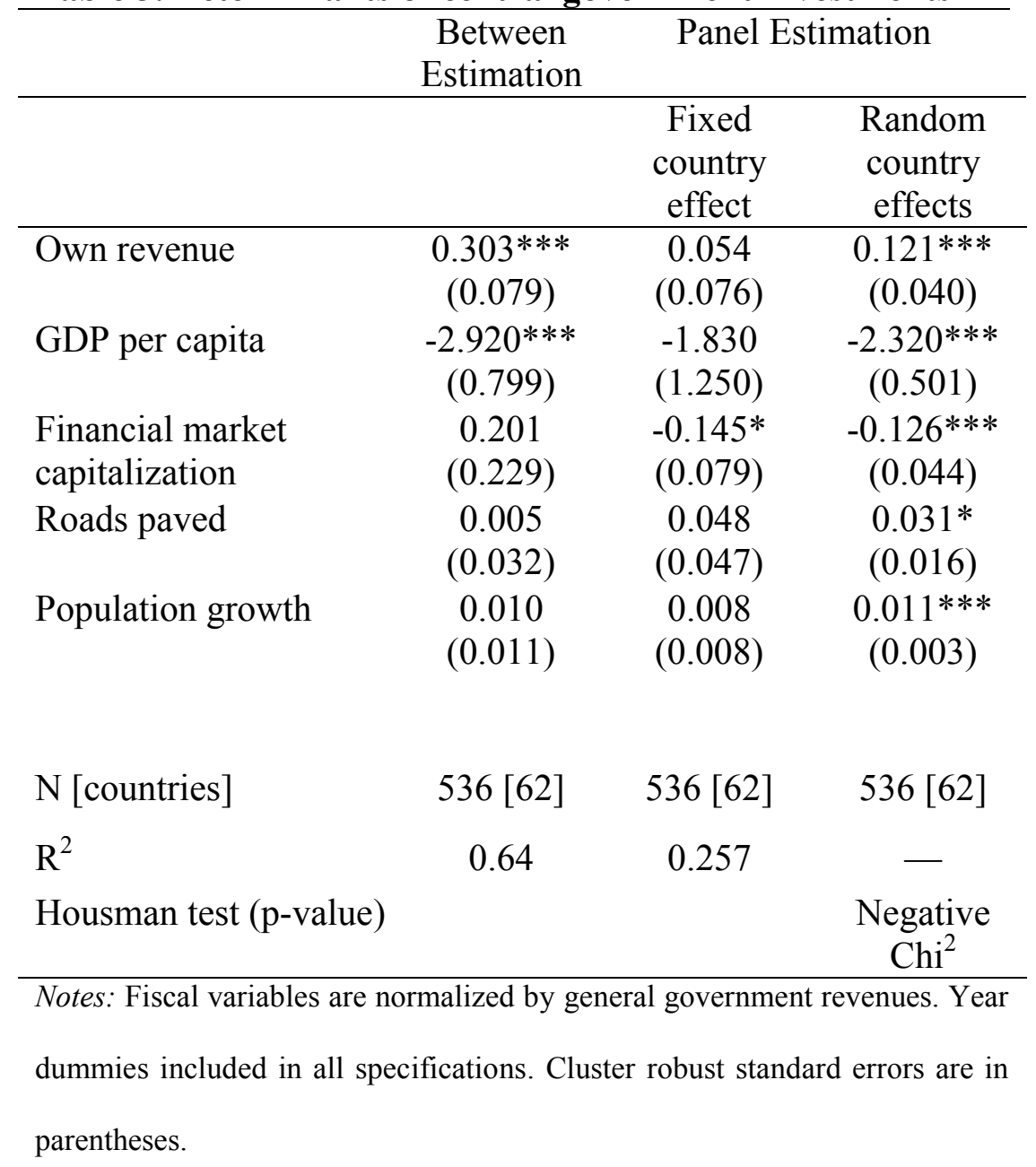


Table 4. Determinants of central government investments

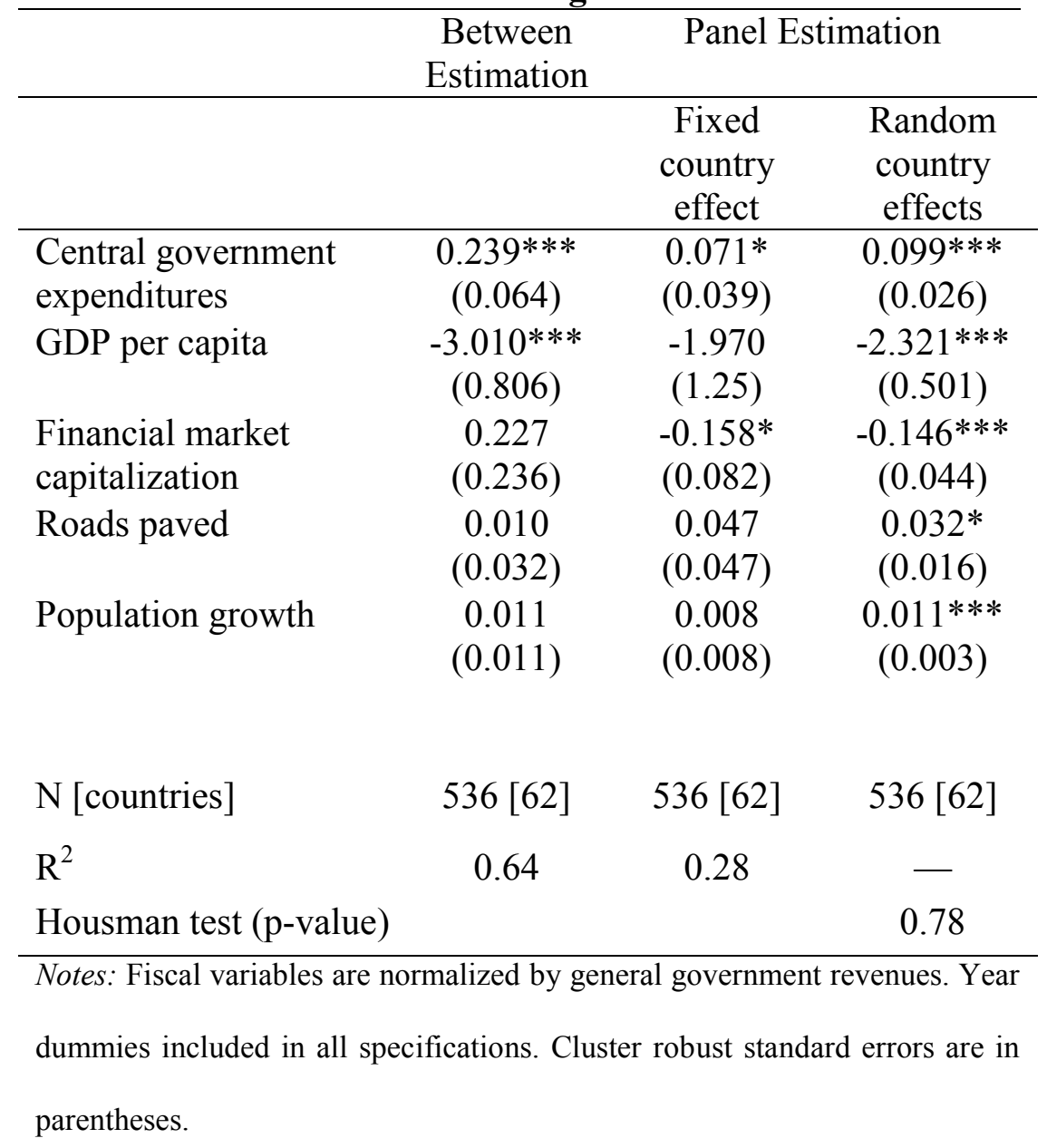


Figure 1. Decentralization of recurrent and capital expenditures, 1997-2008

\section{Capital}

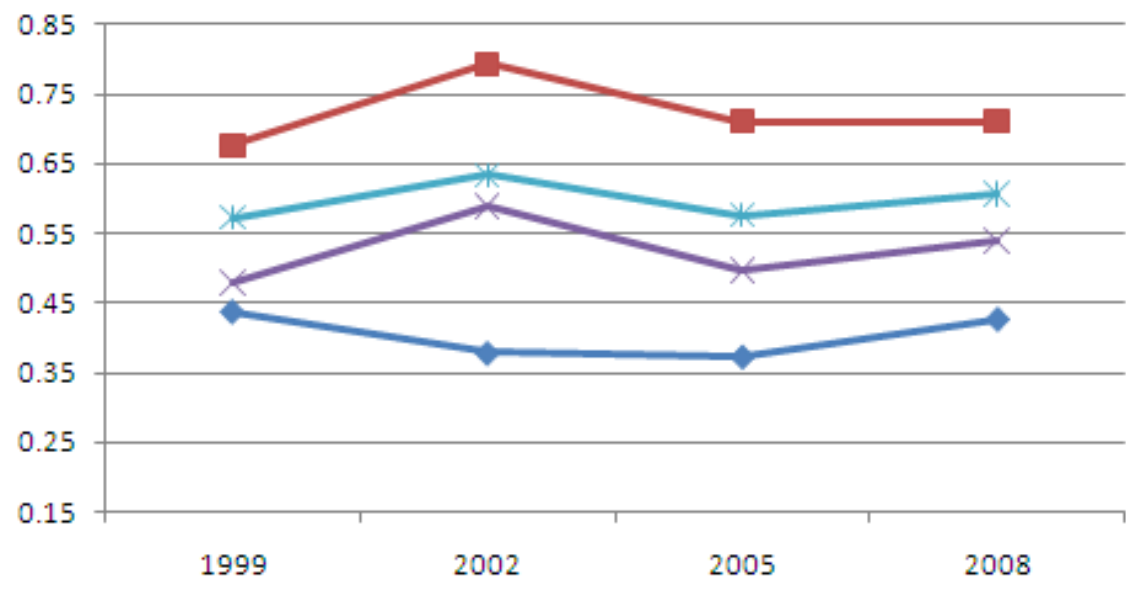

Recurrent

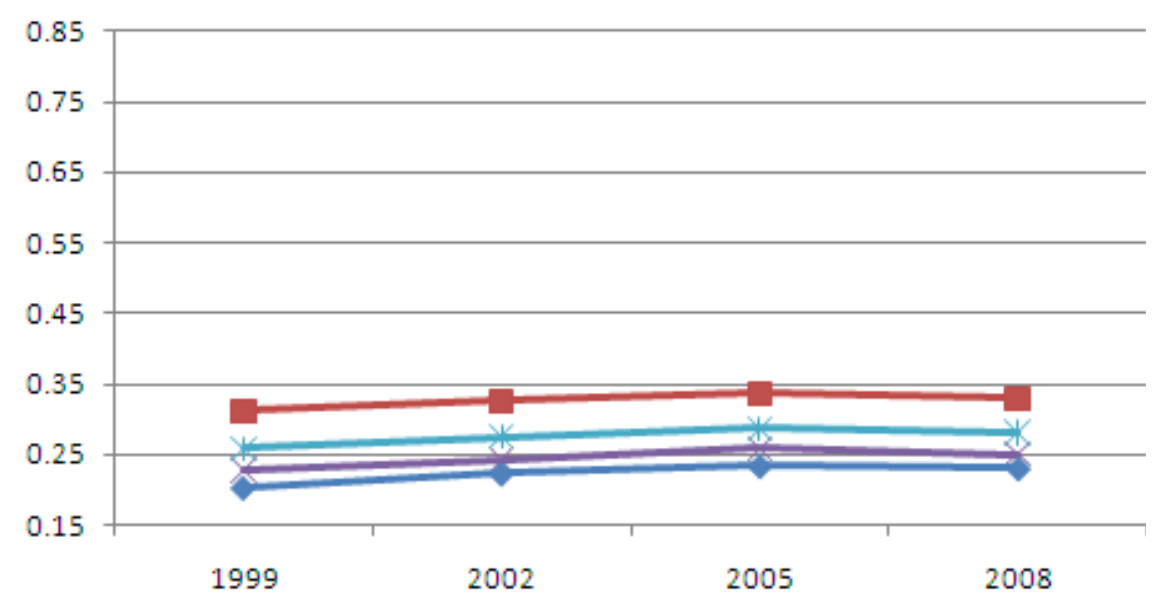

$\longrightarrow \mathrm{OEC} \leadsto \mathrm{LMC} \leadsto \mathrm{UMC} \leadsto$ World

Source: Prepared by authors based on data reported in IMF (2010)

Notes: The sample includes 39 countries, out of which 6 lower middle income, 10 upper middle income, 2 non-OECD high income, and 21 OECD countries. 
Figure 2. Capital grants as a share of total grants, 1993-2008

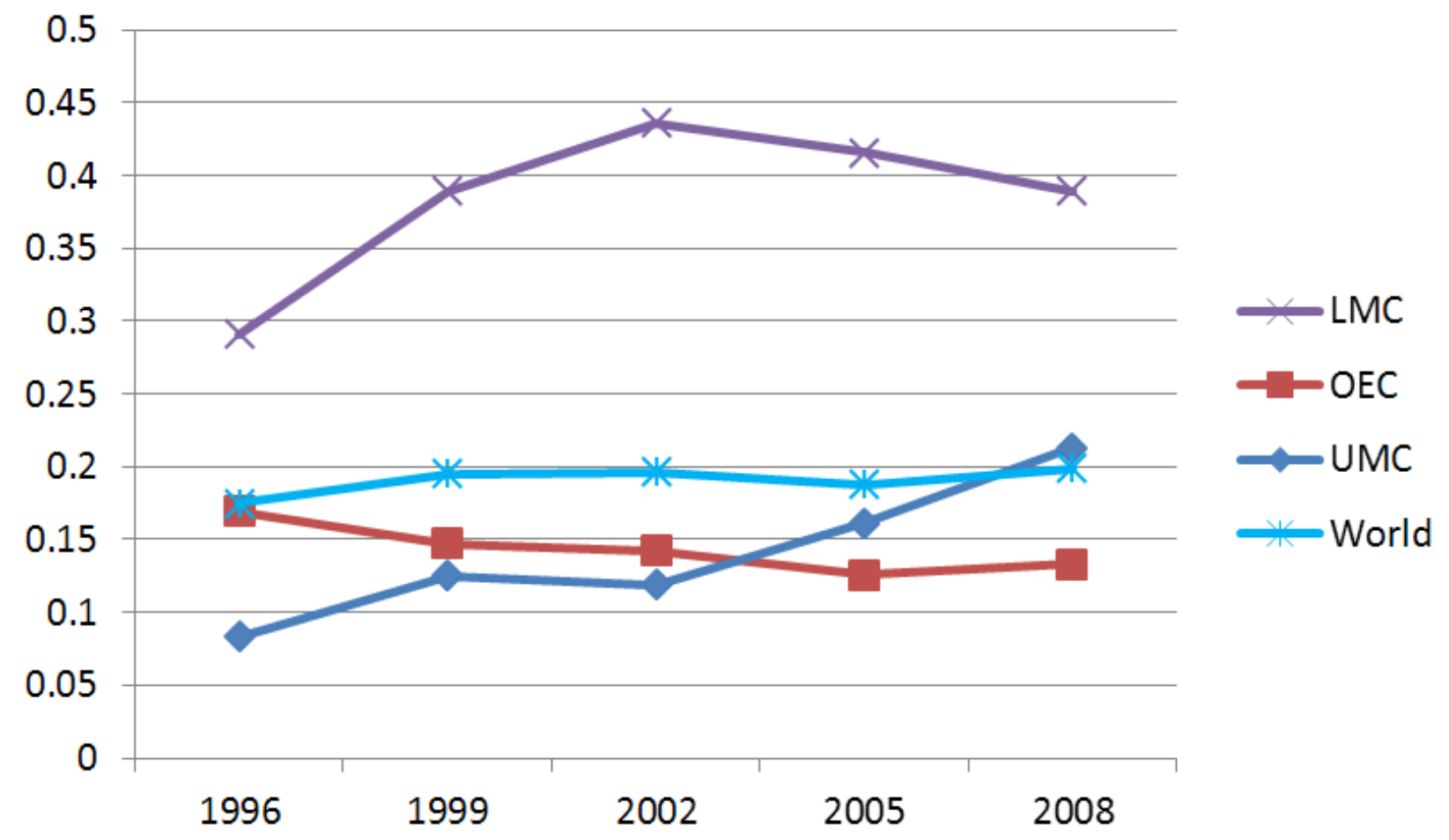

Source: Prepared by authors based on data reported in IMF (2010)

Notes: The sample includes 44 countries, out of which 1 low income, 9 lower middle income, 9 upper middle income, 3 non-OECD high income, and 22 OECD countries. 
Figure 3. Capital grants as a share of subnational capital investments, 1997-2008

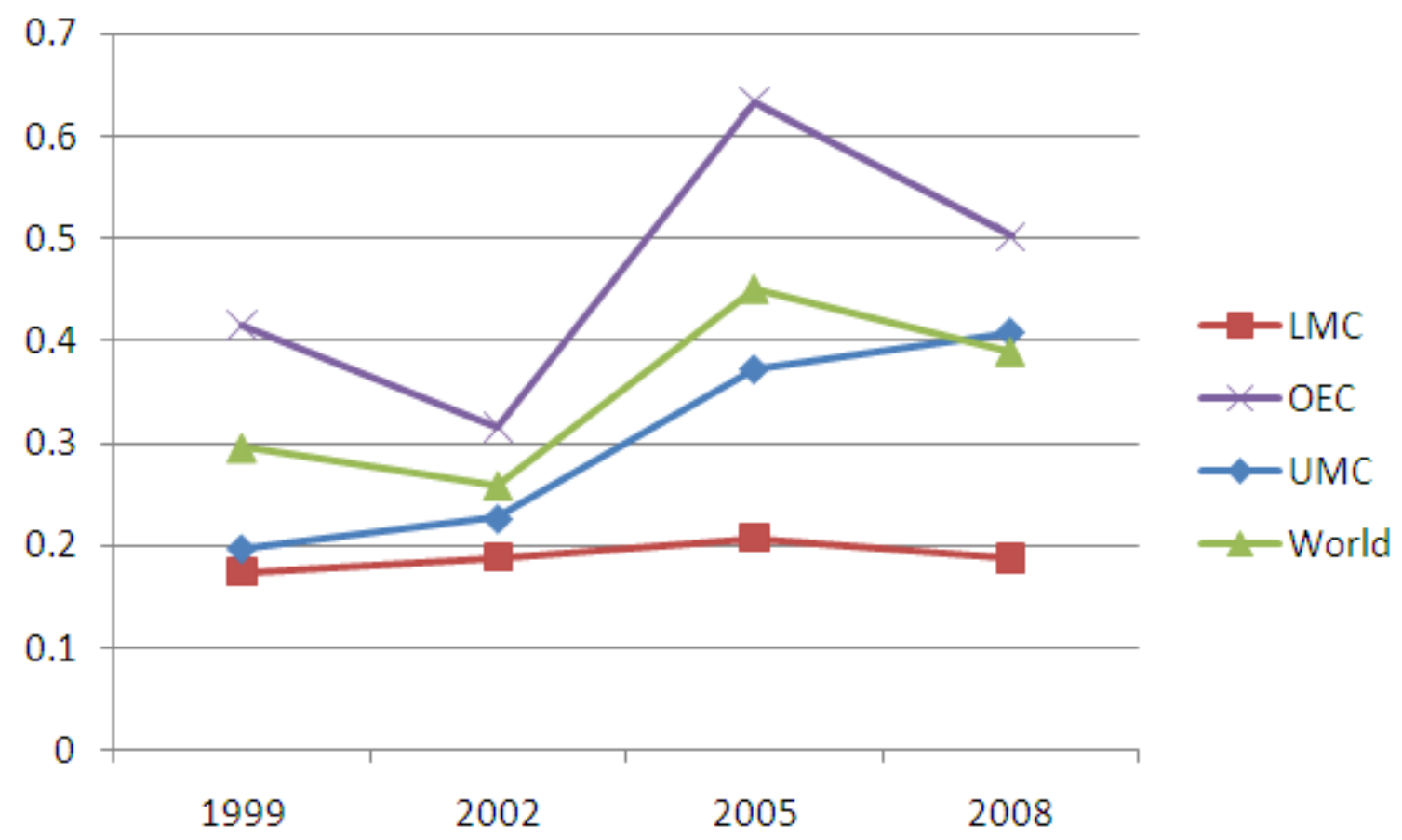

Source: Prepared by authors based on data reported in IMF (2010)

Notes: The sample includes 33 countries, out of which 1 low income, 7 lower middle income, 7 upper middle income, 2 non-OECD high income, and 16 OECD countries. 


\section{Data appendix}

This appendix describes construction of our variables.

The fiscal variables are obtained from the IMF's 2010 Government Finance Statistics Yearbook (GFS), which reports revenue and expenditures in the GFSM 2001 framework for the period of 1990-2008.

We use the following formulae to calculate the fiscal variables respectively:

Gross subnational revenue $\left(\mathrm{SGLG}_{-}\right)=$State revenue $\left(\mathrm{SG}_{-} 1\right)+$ Local revenue $\left(\mathrm{LG}_{-} 1\right)$

Total govt revenue $=$ Gross central revenue $\left(\mathrm{CG}_{-} 1\right)+$ Gross subnational revenue

(SGLG_1) - grants given by subnational govts (SGLG_263) - grants given by central govt (CGx_263)

Subnational own revenue $=$ Gross subnational revenue $($ SGLG_1) - grants received by subnational govts from other levels of govt (SGLG_133)

Current grants given by central govt (CG_2631)

Capital grants given by central govt (CG_2632)

Net acquisition of nonfinancial assets by central govt (CG_31)

Subnational investments $=$ Net acquisition of nonfinancial assets by states (SG_31)-Net acquisition of nonfinancial assets by local govts (LG_31).

In the formulae, the code in parentheses refers to the corresponding GFS time series. For example, CG_1 refers to the time series with the GFS classification Code "1" for the consolidated central government sector. Where data for the consolidated central government sector were missing, we used instead the sum of corresponding time series for the Budget Accounts (BA) and Extra-budgetary Accounts (EA), for example BA_1+EA_1 in place of CG_1. 
We combine data reported on cash and accrual basis and use whichever is available in a given year. Non-fiscal data derive from the World Development Indicators Online:

GDP per capita capitalization

Roads paved

Population growth
Real GDP per capita is in constant 2000 international dollars. Data was reported adjusted by the Purchasing Power Parity index.

Value of stocks traded was used to proxy for the level of financial infrastructure development. Variable was measured as a percentage of GDP.

Roads paved were used to proxy for existing level of capital infrastructure. Variable was measured as a percentage of total roads.

Population growth is measured as an annual percentage and is a proxy for the future need of capital infrastructure. 


\section{References}

Ahmad and Searle (2006) "On the implementation of transfers to subnational governments." In Ahmad, Ehtisham and Giorgio Brosio (Eds). 2006. Handbook of fiscal federalism. Cheltenham, UK; Northampton, MA: Edward Elgar.

Albouy, David. 2010. "Evaluating the Efficiency and Equity of Federal Fiscal Equalization," NBER Working Papers 16144, National Bureau of Economic Research, Inc.

Axelrod, Donald. 1988. Budgeting for modern government. New York: St. Martin's Press.

Boadway, Robin. 2004. "The Theory and Practice of Equalization." CESifo Economic Studies, 50:1, pp. 211.

Boarnet, Marlon G. 1998. "Spillovers and the locational effects of public infrastructure." Journal of Regional Science, 38:3, pp. 381.

Boothe, Paul 2007 "Accrual Accounting in the Public Sector: Lessons for Developing Countries," in and Shah, Anwar. (ed) Budgeting and Budgetary Institutions. Public Sector Governance and Accountability Series. Washington, D.C.: World Bank, 2007, 179-201.

Cantos, P., M. Gumbau-Albert, and J. Maudos. 2005. "Transport infrastructures, spillover effects and regional growth: Evidence of the Spanish case." Transp. Rev. (Transp. Rev.), 25:1, pp. $25-50$.

Cromwell, Brian A. "Public Sector Maintenance: The Case of Local Mass-Transit." National Tax Journal, 1991, 44(2), pp. 199-212.

Feruglio, Nicoletta, Jorge Martinez-Vazquez and Andrey Timofeev. 2008. "Assessment of Fiscal Decentralization in Macedonia," ISP Working Paper Number 08-14. International Studies Program, Andrew Young School of Policy Studies, Georgia State University. 
Freire, Mila and John Petersen, eds. (2004) Subnational capital markets in developing countries:

From theory to practice. Washington, D.C. New York and Oxford: World Bank, Oxford University Press.

Government Finance Group, Inc. 1997, “An Analysis of State Bond Banks," Council of Infrastructure. Financing Authorities Monograph No 9, Washington, D.C.

Gray, Cheryl Williamson and World Bank. 1998. Public Expenditure Management Handbook. Washington, D.C.: World Bank.

Herrero-Alcalde, Ana; Martinez-Vazquez, Jorge and Murillo-Garcia, Encarnacion. 2011. "Capital Transfers and Equalization: An Application to Spanish Regions," Publius: The Journal of Federalism, pp.1-29; doi:10.1093/publius/pjr034.

Holtz-Eakin, Douglas and Amy Ellen Schwartz. 1995. "Infrastructure in a Structural Model of Economic Growth." Regional Science and Urban Economics, 25:2, pp. 131-51.

Hulten, Charles R. and Schwab, Robert M. "A Fiscal Federalism Approach to Infrastructure Policy." Regional Science and Urban Economics, 1997, 27(2), pp. 139-59

Laking, Rob. 1999”'Don't Try This at Home? A New Zealand Approach to Public Management Reform in Mongolia," International Public Management Journal, 2, 2: 217-235.

IMF (2010) Government finance statistics yearbook 2009. Government Finance Statistics Division. International Monetary Fund: Washington, D.C.

Lee, Robert D., Ronald Wayne Johnson, and Philip G. Joyce. 2003. Public budgeting systems. Boston, Mass.: Jones and Bartlett Publishers.

Levtchenkova, Sophia and Jeff Petchey, 2007. "A model for Public Infrastructure Equalization in Transitional Economies," In: Challenges in the Design of Fiscal Equalization and 
Intergovernmental Transfers. Jorge Martinez-Vazquez and Robert Searle (ed.), New York: Springer.

Martinez-Vazquez, Jorge 2000. “An Introduction to International Practices and Best Principles in The Design of Capital Transfers," report prepared for the Center for Fiscal Policy, Moscow under USAID funding with Deloitte, Touche, Tomatsu.

Martinez-Vazquez, Jorge, Gustavo Canavire-Bacarrez, and Andrey Timofeev. 2011. "Fiscal federalism and the measurement of expenditure needs: Theory and international practice.” International Studies Program Working Paper 11-??. International Studies Program, Andrew Young School of Policy Studies, Georgia State University.

Mikesell, John L. 1999. Fiscal Administration: Analysis and Applications for the Public Sector. Fort Worth, Tex.: Harcourt Brace College Publishers.

Moak, Lennox L. and Albert Miller Hillhouse. 1975. Concepts and practices in local government finance. Chicago: Municipal Finance Officers Association of the United States and Canada.

Musgrave, Richard Abel. "The Nature of Budgetary Balance and the Case for the Capital Budget." The American Economic Review, 1939, 29(2), pp. 260.

Nenkova, Presiana. 2006. "The mechanism for determination, allocation and management of capital transfers in Bulgaria - state of play, issues and improvement opportunities," Report prepared For the Conference on Subnational Transfers and Regional Development in the CEE Region, Bucharest, June 13-14, 2006.

OECD/World Bank. 2003. Survey of Current Budgetary Practices for 30 OECD countries and 30 non-OECD countries (ocde.dyndns.org). 
Pagano, Michael A. 1993. "Balancing Cities' Books in 1992: An Assessment of City Fiscal Conditions." Public Budgeting and Finance, 13:1, pp. 19-39.

Pereira, A. M. and O. Roca-Sagales. 2003. "Spillover effects of public capital formation: evidence from the Spanish regions." Journal of Urban Economics, 53:2, pp. 238-56.

Petchey, Jeffrey; MacDonald, Garry;2007. "Financing Capital Expenditures through Grants," in Boadway, Robin and Shah, Anwar (eds.) Intergovernmental Fiscal Transfers: Principles and Practice. Public Sector Governance and Accountability Series. Washington, D.C.: World Bank, 425-51.

Premchand, A. "Capital Budgets: Theory and Practice," 2007, in Anwar Shah, ed. Budgeting and Budgetary Institutions. Public Sector Governance and Accountability Series. Washington, D.C.: World Bank, 89-108.

Rioja, F. K. 2003. "Filling potholes: macroeconomic effects of maintenance versus new investments in public infrastructure." Journal of Public Economics (J. Public Econ.), 87:9-10, pp. 2281-304.

Spearman, Kay 2007. Financial management for local government. London: Earthscan.

Sienkiewicz, P. (2004), "Comparing International Experiences: Emerging Markets of Local Borrowing?" in: Sienkiewicz, P. (ed.), Local Government Borrowing: Risks and Rewards: A Report on Central and Eastern Europe, OSI/LGI, Budapest, pp. 385-424.

Valley, Robert C. G. (2001) Indonesia: Financing Small Scale Urban Infrastructure in the Era of Decentralization. Asian Development Bank.

Vogt, A. John and Shah, Anwar. "Local Capital Budgeting," Local Budgeting. Public Sector Governance and Accountability Series. Washington, D.C.: World Bank, 2007, 307-60. WDI Online. World Development Indicators Online. World Bank Group, Washington, DC. 
Wurzel, E. (1999), "Towards More Efficient Government: Reforming Federal Fiscal Relations in Germany", OECD Economics Department Working Papers, No. 209. 